\title{
Factors and Utilization of Discourse Power in Business Model in New Media Era
}

\author{
$\mathrm{Xu}$ Jie \\ College of Economics and Management \\ Zhejiang Business Vocational College \\ Hangzhou, China \\ 65166756@qq.com
}

\begin{abstract}
This paper provides connection between discourse power and business model within New Media Era context. Through analysis and categorization on successful internet company marketing cases in China, it indicates three main factors in the construction of discourse power, namely popularity gathering, knowledge exposition and capital accumulation. By putting forward two utilization ways commonly used today, online to offline and single to diversity, it shows how power functions in creating extra value discourse.
\end{abstract}

Keywords-discourse power; business model; new media; marketing

\section{New Business Model IN NeW Media ERA}

Business Model, a hot phrase academically describes how an organization creates, delivers, and captures value in economic, social, cultural or other contexts, has drawn wide attention in economic field.[1] With the coming of the New Media Era, Chinese business model has witnessed great changes these years. Traditional model no longer goes easy with the development of new media era. Confronting with the phenomenon of offline marketing gradually shifting to online, scholars today seek to summarize new models emerged with the new era.

4P principle in traditional marketing puts its focus on production, and gives emphasis on its price, place and promotion. However, under new media era, the "marketing target", consumer, has played multi-functions in acting as "target", "advertiser" and "channel". Therefore, business model emerged in this era cores in customer rather than product. According to Luo \& $\mathrm{Li}$, there are several key factors in the new-media-era model, including: [2]

- community creating value interaction

- platform strengthening the distribution ability under Information and Communication Technology

- crossover satisfying potential demand

- resource syndication \& product design balance demanding and supply

Viewing from the above information, highly spread and valued information in this new era attaches importance on "people", who acting both value receiver and distributor. These changes force new business model focusing consumer demand

This work is supported by the Planning Routine Program of Hangzhou Philosophy and Social-Science Organization, namely "The Research of Discourse Power Battle in Business Model under All-Media Era" granted Z16JC055. and resource distribution, so as to create, deliver and capture maximum value.

Changes from single value chain to "value shop" and "value network" calls for new models. [3] In this century, under internet context, a 4I Theory is put up to illustrate the online marketing principle, namely:

- Interesting: draw the interest of the target

- Interests: meet interests of the consumer both physically and psychologically

- Interaction: make full use of the web characteristic to interact with consumers

- Individuality: categorize specific group to endeavor the identification

\section{FACTORS IN DISCOURSE POWER CONSTRUCTION}

Van Dijk pointed out that discourse power within media has a dominant effect and plays a huge role in determining the patterns of access. [4] This domination, along with the change of channel, speed and model of information transformation, has come to a greater range. It enters into every corner of the society, and goes far beyond the influence in traditional days. The merger of internet companies Youku and Todou, Uber and Didi in internet field, rising of penetrative advertisements in Hunan's TV's show "Where Does My Dad Go", 1 billion box office of "Monkey King: Hero is Back" in movie industry, an estimated 0.3 billion value in web celebrity "Papi", numerous business cases in Chinese internet market have proved the power of discourse in creating values.

Holding discourse power is of great support in today's marketing. The newly-emerged phenomenon of new business models, including web celebrity economy, fan economy, community economy, sharing economy, vividly depicts the role discourse power played in this era. In the process of analyzing and categorizing these cases, fundamental factors in discourse power construction can be sorted into three main factors:

\section{A. Popularity Gathering}

There is a strange phenomenon in Chinese business field, namely "three brothers, eldest fight the middle, and the little disappear". Case like battles among Jiaduobao (shorten as JDB), Wanglaoji (shorten as WLJ) and Heqizheng (shorten as HQZ) can be shown as a vivid example. It may seem to be 
puzzling why HQZ's saving in resource and capital in turn expels company from the competition. However, viewed from discourse power perspective, the reason becomes clear.

As illustrated in $4 \mathrm{I}$ principle, popularity gathering is the most basic element in discourse power construction. On one hand, be it a product, website or brand, losing popularity means being pushed away from the competition. On the other hand, once becomes a hot spot, a chance is falling to enhance the discourse power, even during a fleeting period.

Taking this case as an example, in April 2012, Guangzhou Pharmaceutical Group sued JDB Group for using their brand and finally forced JDB change the nationaldominated brand WLJ into JDB. This suing case aroused wide attention all over the country. From Baidu Index, the searching index tendency flow of WLJ JDB and HQZ in 2012 can be shown as below:

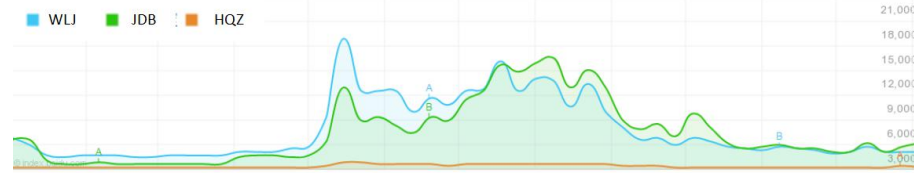

FIGURES FROM INDEX.BAIDU.COM

Fig. 1. Baidu Index of WLJ JDB and HQZ in 2012

As shown above, the index of three brands did not differ greatly before March, 2012. However, the coming of suing case greatly promotes the index of both WLJ and JDB. In July, with the help of suing case and high-frequency advertisement, JDB even surpassed WLJ. Meanwhile, the index of HQZ remained low during this period. The result of this battle is known to all: JDB, fameless before 2012, now ranks unshakable No.1 in the herbal medicine market. According to the "Report of 2016 Chinese Beverage Industry" issued by China Food Industry Association, JDB's sharing rate in canned drink market was up to $70.7 \%$. [5]

Thanks to the information flow across the Web, battle between two big companies will normally arouse great interest among the mass. Similar to the pattern of this case, with the help of the new media, this kind of cases draws interest national wide, forms an internet "hot topic", gathers great popularity, promotes the brand cognition and recognition, and strengthens company's power in the industry context.

\section{B. Knowledge Exposition}

Popularity is a fundamental factor, but using it alone is far away from seizing discourse power. In accordance with $4 \mathrm{I}$ theory, business model should meet targets' interest. New media era brings, shares and creates countless information to "people". In this trend, knowledge becomes another predictable factor.

Knowledge is different from information. In 1987, A.N.Smith and D.B.Medle classified 4 elements in how people learn objective world, known as Fig. 2:[6]

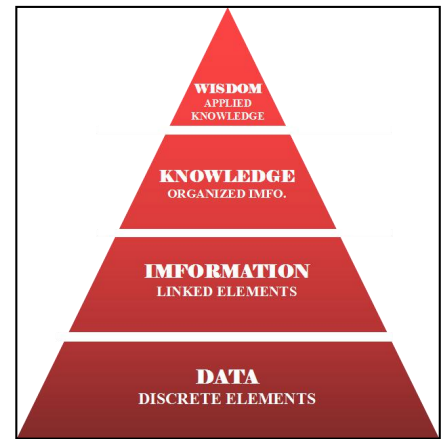

Fig. 2. Four Elements in Learning Objective World

Shown above, the basic factor people can get through physical way is data and information. But for self-growth, one need to learn more so as to satisfy "interest" in living need, safety, social function, respect and self-satisfaction.

Under this circumstance, culture industry is blowing in new media era. In this industry, knowledge and wisdom is wildly spread to attract readers. Luo Zhenyu, a former CCTV producer, quit his job and created a Wechat account "Luoji Siwei" (Luo's Logical Thinking), sending a daily informative 60 -second sound to his subscribers. Along with weekly a theme-based video covering history, society and economy posted in we-media Youku, Luo's company now has an estimated value up to 1.32 billion RMB. In the process of creating, sharing, using and managing knowledge and information, Luo has successfully created his "commercial empire", which academically named "community".

"Community" along with "community economy" becomes a hot word in business model. Especially in Wechat App, numbers of public account become "Web celebrity", attracting millions of fans, and boosting their valuation to billions RMB. B.Q. Luo put forward four steps in establishing community, namely: [7]

- Us: categorizing groups with same background, interest, generation, and ext.

- Enemy: confronting an enemy to enhance group cohesiveness in the antagonism

- Cause: finding a cause to fight the unfair and unreasonable, setting up the rightness in the group

- Follow: leading the group by giving values and identification to the members.

In this process, a leader in community has the power to urge his members, whom named by Gustave Le Bon "the crowd with popular mind", to follow him. [8] Thus, the discourse power creates economy value.

This pattern is commonly seen in culture industry, where knowledge is highly valued. The movie "Monkey King: Hero is Back" is a typical example in this pattern. By gathering $80 \mathrm{~s}$ generation, fighting "enemy" "Tiny Time 4.0" and "Forever Young", the movies taken by famous but unprofessional celebrities, confronting with unfairness in "low quality high return" IP flow, it finally reached 0.96 billion box office income. In this process, millions of fans hold the knowledge 
flag in cartoon fields, shout for the national conscious, and gather into a bigger and bigger group.

To establish the discourse power and become a leader in community in culture industry, one should be outstanding in a group. As the web shields the status, wealth and appearance, knowledge becomes a key factor in this invisible world. The knowledge explosion follows with topic, popularity, fans and money. Domination in one field will creates great value.

\section{Capital Accumulation}

Besides fundamental "popularity", the further element "knowledge", the most important element is capital.

Cases can be shown in the hot spot "sharing economy". From the battle between Didi Kuaidi and Uber, to the fight today between the bicycles sharing field, these three elements have exerted huge effect on the market. Popularity directly gives market focus to top ones, knowledge is a supplementary in grabbing market sharing, but the battle in essential is the battle of capital.

After merger with Kuaidi in 2015, Didi enters into the battle with Uber. At that time, financing becomes a growing important mean. Viewing the financing statistic of Didi and Uber, we can see the role of capital played in the battle.

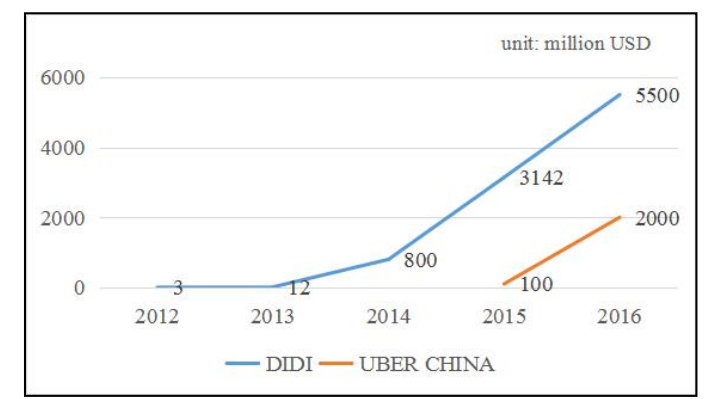

Fig. 3. The Financing of Didi and Uber China from 2012-2016

In the capital battle, Uber China has dramatically fallen behind; no wonder Didi today has an absolute discourse power in the car-sharing market.

The sharing bicycle economy can be seen as a copy of the former. Mobile, the No.1 in this field, gets most financing from Tecent, and OFO, the second best in this field, grows with the financing from Didi. The bicycle sharing market is somewhat a mirror of car-sharing market.

Capital is of great importance in the battle of discourse power. It brings talent, publicity and fund for further research. It is helpful in improving performance, competitive, innovation, and contributes to integration and continuous improvement of a company. In traditional field, capital possessors in politics, economics and culture field have a dominating discourse power in influencing followers. New media era under WEB 2.0 brings changes in many aspects, gives attention and chances to the unimpressive, but never change this business rule.

\section{UTILIZATION OF DisCOURSE POWER}

Linguistics believes that societies are organized first and foremost by texts. The game in discourse power is originated from its internal motivation in utilizing discourse power. Under this power, discourse has an unaware effect on communities, driving followers in the context purchasing products offered. Therefore, seizing discourse power means obtaining the right to speak in a specific context, and an insurmountable advantage in further marketing. For company development, utilizing discourse power is a necessary and essential step in innovating business model. Commercial cases in utilizing discourse power appeared mostly in the following two ways:

\section{A. Online to Offline}

On way to utilize the discourse is to expand the channel. Discourse power is mostly and easily constructed online. But it should be well aware of that with the growth of a company, power offline is an inevitable choice. After all, business model, be it online or offline, is in nature lies in the real market.

Citing "Luo's Logical Thinking" for example, after building its community and successfully expand book-selling business to all-category, it began to utilize its power in 2015. This company was no longer satisfied with "selling knowledge" online. Instead, it went offline and prepared its first "New Year Speech". On Dec.31th, 2015, Luo Zhenyu, together with his friends, Cheng Wei from Didi and Duan Yi from Fangduoduo, gave audience a speech lasting 4 hours. This offline experiment turned out to be a wonderful and successful operation. The tickets sold gained 45 million RMB profit within 2 days, audience rating of this speech ranked No.1 among 11 provincial satellites TV that night. What's more, with this self-media based lecture, Luo Zhenyu's had jumped out of the Wechat context limitation. He transformed his image from an Wechat account-owner to a leader in the new media business field. In other words, his discourse power online gradually shifted offline, and the fruit was obvious: the 2017 lecture following had the power to invite Wangshi, and the 12000-occupation capability stadium was almost full.

Luo's success is only a shadow in the new business model. Various winners are trying to expand their influence from their own "community" to offline society. Or, put it in other word, from the minority to majority. This is a "MUST" for them to expand the business kingdom. The utilization of business power is a necessary tool.

\section{B. Single to Diversity}

If online to offline is the utilization in the channel, then single to diversity is the utilization in the chain field.

Once owning the discourse power, the company or brand has followers with full trust. Winning potential consumers shares great advantage in exploring new area. 360, the discourse power in anti-virus software field, now has his own software, hardware, and even mobile phones. Xiaomi, the one who accumulates big camp of fans, has entered into home appliance field. Once holding the discourse power, growing companies will no longer be satisfied with limited products, instead, it will take advantage of the power to explore new product chain.

Didi is a vivid example. Its first appearance before the mass is the "price battle" with Kuaidi. At that time, both companies represent new "cheap and quick" riding model. After winning power in Chinese market, financing tides come. It is reported that on the first half of 2017, it has got 5.5 billion USD 
financing. However, the money will be no longer used to be traffic allowance for customers. After the merger with China Uber and the governmental publishing of new rule for online booked car, Didi actively expanded its field and changed its competition focus. Till now, besides the traditional taxi and "fast ride", Didi also has his "professional ride" and on-way ride, the former of which makes profit, while the latter enhances customer loyalty.

\section{CONCLUSION}

Discourse power used to be highly valued in political, social and media field. When it enters into economical field, the role it plays is also appalling. In order to explore the relationship between discourse power and business model changed in new-media era, this paper analyzed various successful marketing and commercial cases, including JDB, WLJ and HQZ, Didi and Uber, Luo Zhenyu's Wechat community, and finally summarize these into a model. It divides the development of discourse power into two stages, growing stage for construction and developing stage for utilization. In former stage, it gives three main factors, popularity, knowledge and capital, illustrating elements to seize the power. While in latter stage, it shows two shifting ways in channel and product. Specific information can be shown as follow:

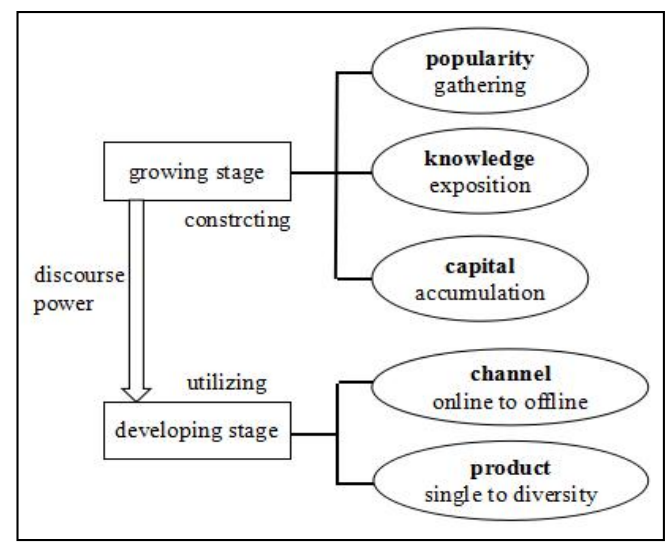

Fig. 4. Factors and utilization of discourse power in the two stages of companies
Different from the other fields where discourse power is a "power transfer", in economic field it is a kind of "power transform". Discourse power goes along with the growth of a company. In the growing period, it needs to be constructed on the basis of the popularity gathering, knowledge exposition and capital accumulation. But once power is successfully constructed, companies is urged to enter the stage of utilizing discourse power to explore new field under the expansion need, be it new in channel or in field. To the companies, discourse power transforms into a kind of winning status, attracts its followers enhancing the market discourse.

\section{ACKNOWLEDGMENT}

J. $\mathrm{Xu}$ thanks Hangzhou Philosophy \& Social-Science Organization and Zhejiang Business Vocational College in financing and supporting the research, and group colleagues in completing this paper.

\section{REFERENCES}

[1] A.Osterwalder, Y. Pigneur, A. Smith, and 470 practitioners from 45 countries, "Business Model Generation", self-published, 2010.

[2] M. Luo, L.Y. Li, "The Innovation of Internet Business Model. Chinese Industry Economy", Vol.1, pp. 95-107, 2015. (In Chinese)

[3] C. Stabell, O.D. Fjeldstad. "Configuring Value for Competitive Advantage: On Chains, Shops and Networks", Strategic Management Journal. Vol.18, pp: 413-437, 1998.

[4] Van Dijk, Teun, "Discourse Power and Access", Texts \& Practices Readings in Critical Discourse Analysis, pp:84-104, 1995

[5] China Food Industry Association, "Report of 2016 Chinese Beverage Industry", 2016. (In Chinese)

[6] A.N. Smith, D.B. Medley., Information Resource Management. Cincinnati (Ohio): South-Western Publishing Co., 1987.

[7] B.Q Luo, "Celebrity Community Marketing", Technology Wind, Vol.6, pp:80, 2016. (In Chinese)

[8] G.L. Bon, "The Crowd: A Study of the Popular Mind", New York: Dover Co., 2002. 